\title{
Automation system spraying desinfectant at Universitas Musamus
}

Reza Zubaedah*, Stanly Hence Dolfi Loppies, Loudry Loudry

Departement of Information System, Faculty of Engineering, Universitas Musamus, Merauke 99600, Indonesia

\begin{abstract}
During the pandemic the learning process was conducted online and partly done face-to-face so that every day there are still students and employees who are in the campus environment. One of the prevention of covid transmission is done by spraying disinfectant when passing through the front gate of the campus. A design a prototype of an automatic disinfectant spray system and build a system on the prototype that can provide real time information related to monitoring the contents of the disinfectant tank by designing hardware. The results of the research built a disinfectant spraying automation system in front of the entrance gate of Universitas Musamus, to get results that prove that the system performance has been running as expected, there are several tests carried out such as tool testing and measuring the reading distance of the ultrasonic proximity sensor, and testing. sending SMS alert. How to provide information that the liquid in ultrasonic proximity sensor, and testing. sending SMS alert. How to provide information that the liquid in
the tank has run out. Sensor sends a status signal for the disinfectant liquid level after spraying, a warning SMS is sent went the distance of disinfectant liquid and the ultrasonic sensor at a predetermined threshold.
\end{abstract}

Keywords: Prototype, System automation, Disinfectant.

\section{Introduction}

Universitas Musamus is a public university in Merauke, Papua which was established on August 16, 2006. This university is a status transition from the Merauke Technical High School (STTM) to Universitas Musamus and now has 6 Faculties including Faculties. Agriculture, Faculty of Engineering, Faculty of Economics and Business, Faculty of Teacher Training and Education, Faculty of Social and Political Sciences, Faculty of Law and 9339 students and 549 employees. Corona virus disease 2019 (COVID-19) is a large family of viruses that cause disease in humans and animals [1]. In humans, it usually causes respiratory infections, from common to serious diseases such as Middle East Respiratory Syndrome (MERS) and severe acute respiratory syndrome (SARS) [1]. On 30 January 2020, WHO declared the new outbreak (COVID-19) a Public Health Emergency of Concern for the World. To respond to COVID-19, critical readiness and response is needed, such as equipping health workers and facility management [2].

Health services with information, procedures, and tools necessary for safe and effective work. Starting from March 17, 2020, the teaching and learning process from the PAUD, SD, SMP, SMA / SMK and State and private / foundation universities to be temporarily rested until an unspecified time limit in an effort to preven COVID-19, starting on the 10th May 2020 for academic activities at Universitas Musamus, but only for 8th

* Corresponding author: reza@unmus.ac.id semester students and above to conduct thesis guidance and registration of proposals and theses. Every day the vehicles that enter the Universitas Musamus area reach 80 motorbikes and cars. Universitas Musamus implements a prevention system by spraying disinfectants at the gate to prevent the possible spread of the COVID-19 virus. So, in this COVID-19 virus outbreak, everyone who wants to enter the Universitas Musamus area is required to go through the spraying of vehicle disinfectants at the gate.

Based on the results of interviews with the team for making disinfectant sprayers on June 12, 2020 at Universitas Musamus, it was revealed that the equipment designed for spraying disinfectant liquid and filling water into the storage tank works manually, when the switch is on, the water pump will immediately work spraying, and when the switch is turned off, the pump will go out. The weakness of this system is when personnel forget to turn off the pump, the disinfectant liquid spraying process will continue to spray, resulting in waste in the use of disinfectant fluids, and personnel must frequently check the disinfectant liquid tank so that it does not run out and when the liquid runs out, personnel must contact the car. tank to fill water as a material for disinfectant liquid and in the process sometimes there is a delay in contacting the tank car because it is too late to see that the disinfectant liquid in the tank will run out.

From the above problems, it is necessary to design a tool that can spray disinfectant automatically so that 
spraying can be carried out optimally without having to experience wasted disinfectant liquid. Time Based Automatic Crop with Real Time Clock (RTC) And Ultrasonic Sensor And Notification Via SMS [3]. This research discusses a system that functions to water plants automatically based on the time set in the program and the system will provide information to the user when the water in the container will run out. Based on the tools that have been designed before, there are still weaknesses. The previous weakness was not being able to provide information to users when the water in the tank was running low, therefore it was necessary to design an automatic disinfectant spraying device at the gate of Universitas Musamus so that the spraying process could be maximized so as not to spend a lot of money in using disinfectant liquid. It can also provide information to personnel when the water in the tank is running low.

\section{Theoretical Review}

\subsection{Covid 19}

On January 30, 2020, the World Health Organization (WHO) declared Corona virus disease 2019 (COVID19) a Public Health Emergency of International Concern (PHEIC) / Public Health Emergency that Concerned the World (KKMMD) 1. On February 12, 2020, WHO officially designated the novel coronavirus disease in humans as Corona virus disease (COVID-19) [1].

\subsection{Prototype}

Prototype is a model or simulation of all aspects of the actual product to be developed, this model must be representative of the final product [4]. In system development, there is often a situation where system users actually have defined general or purpose of the software even though they have not defined in detail the input, process and output [5]. Meanwhile, in the system development process, it is not uncommon to face doubts about the effectiveness, efficiency and quality of the algorithms that are being developed, the adaptability of the system to the operating system or the appearance that is being designed [6]

\subsection{Arduino}

Arduino is an open source hardware prototyping platform based on hardware and software [7]. Arduino is a microcontroller board based on the ATmega 168. Arduino has 14 input / output pins of which 6 pins can be used as PWM outputs, 6 analog inputs, a $16 \mathrm{MHz}$ crystal oscillator, a USB connection, a power jack, an ICSP head, and a reset button. Arduino is able to support a microcontroller connected to a computer using a USB cable [8].

\section{Design}

\subsection{Program Flowchart}

Flowchart program or chart program is a chart that describes in detail 1-Step -step of the process of programs contained in the Figure 1.

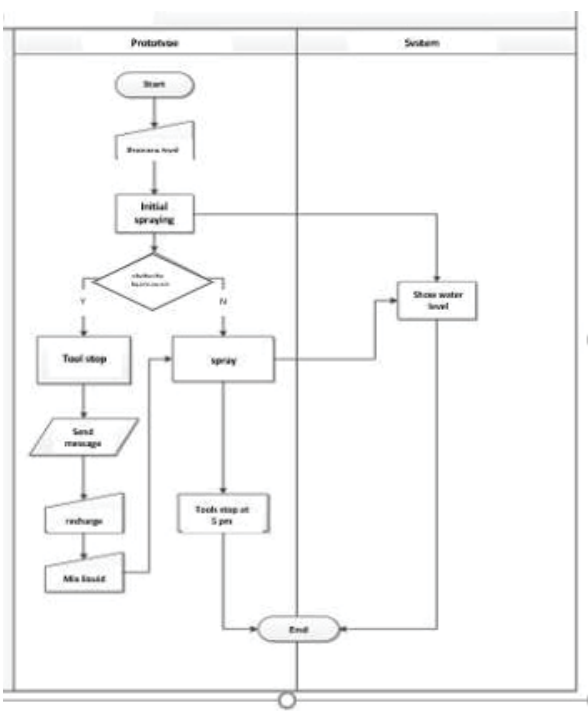

Fig. 1. Flowchart program.

\subsection{Hardware System}

Hardware design is depicted to show what tools and sensors are used in building this disinfectant spraying system and can show in Figure 2.

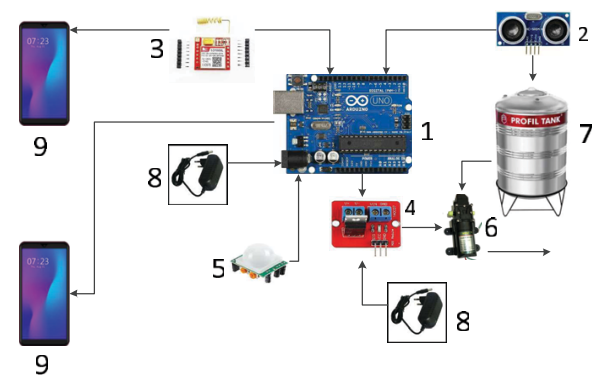

Fig. 2. Hardware design

Information:

1. Arduino uno is an open-source single-board micro controller, designed to facilitate the use of electronics in a variety of fields. 
2. Ultrasonic Sensor HC-SR04 to measure the level of water in the disinfectant tank

3. SIM800L will send an SMS when the disinfectant liquid in the tank reaches the threshold

4. Irf520 mosfet drive module useful for controlling the stop or start of the water pump

5. PIR (Passive Infra-Red) sensor: When someone walks past the sensor, the sensor will pick up passive infrared rays emitted by the human body which has a different temperature from the environment so that the device can spray disinfectant

6. RT-18A pump useful for drawing water in the tank and spraying disinfectants

7. Disinfectant water tank serves to accommodate disinfectant liquid

8. 12-volt adapter for supply the microcontroller device voltage

9. Mobile for admin can find out the distance of the disinfectant fluid in the tube in real time and the tank car attendants can receive information that the disinfectant liquid will run out

\subsection{User Interface}

\subsubsection{Form main menu}

Shows a form where the admin can find out the distance of the disinfectant fluid in the tube in real time. If the disinfectant liquid shows a value of $0 \mathrm{~cm}$, it can be concluded that the disinfectant tube is fully filled and vice versa if the disinfectant liquid shows a value of 50 $\mathrm{cm}$, it can be concluded that the disinfectant tube is not filled with the disinfectant liquid shown in Figure 3.

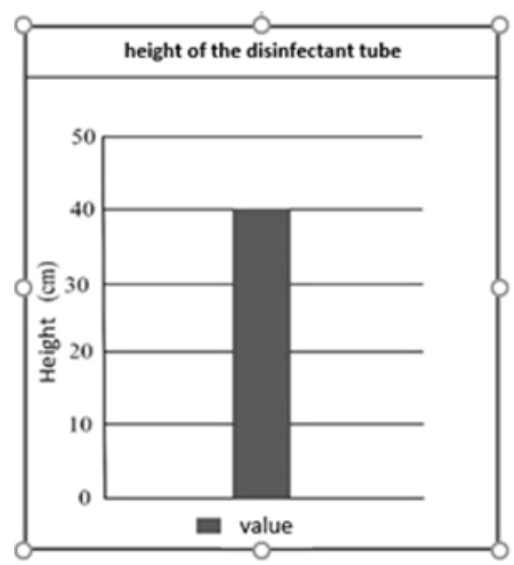

Fig. 3. Form utama

\subsubsection{Menu form SMS}

Form SMS where the designated destination number, namely the number of the tanker driver, will receive an SMS message information sent by the device that the disinfectant liquid will run out. So that there will be no delay in refilling the disinfectant liquid shown in Figure 4.

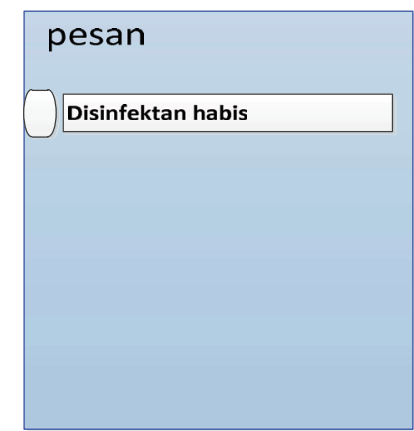

Fig. 4. Form SMS

\section{Result}

\subsection{Design Implementation}

The result obtained from this study are that authors have made a hardware and software tp build a web based disinfectant protection automation system.

\subsubsection{Hardware manufacture results}

Prototype for the disinfectant spraying system and the resulting website applicatin is in the form of a smallscale three-dimensional imitation or commonly known ad a mockup. In detail, the prototype system can be seen in Figure 5.

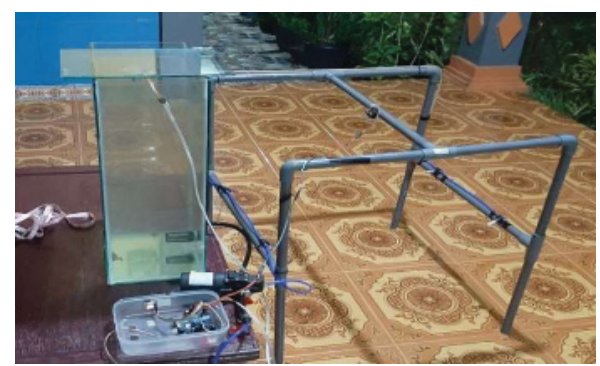

Fig. 5. Results of Software Development

Making software is done by implementation programming language such as Javascript and PHP to produce a website application based for user interface. website application that was built serves as a medium for monitoring the mobility of the use of disinfectant liquid water during working hours can see in Figure 6. 


\section{Monitorine desinfectant}

\section{height of the disinfectan tube}

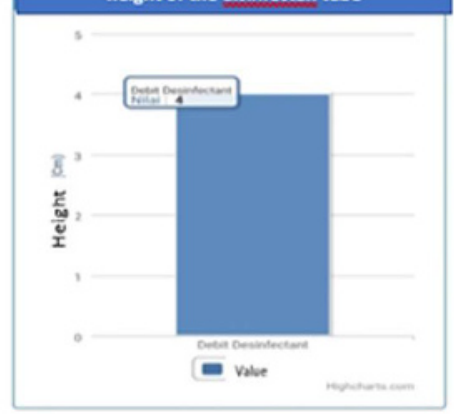

Fig. 6. Main Menu Form

\subsection{Testing}

In this study, to obtain results that prove that the system performance has been running as expected, the tests carried out include with sensor tool testing.

\subsubsection{Passive Infrared Sensor read sensitivity}

This stage is carried out to ensure that the process Passive Infrared Sensor readings are in accordance with the conditions set out which will do the spraying in early to determine whether there is fluid in the tank can see at Figure 7.

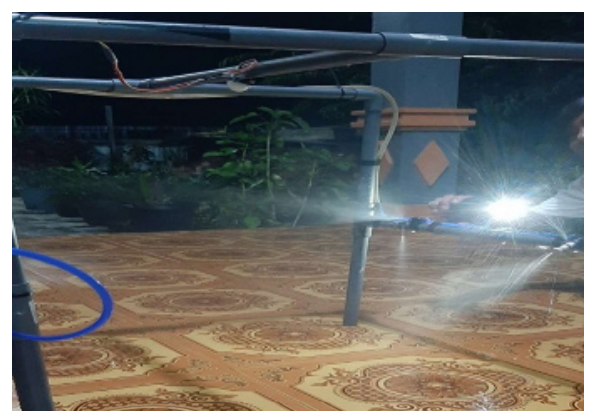

Fig. 7. Initial sparying

4.2.2 Ultrasonic proximity sensor reading distance measurement

Testing the reading distance of the ultrasonic proximity sensor value on the website is done in real time with a distance range of $0 \mathrm{~cm}$ to $50 \mathrm{~cm}$. The test results can be seen in Table 1 below:
Table 1. Ultrasonic Proximity Sensor Reading Distance Test Results

\begin{tabular}{|c|c|c|c|}
\hline \multirow{2}{*}{$\begin{array}{l}\text { Distance } \\
\text { read }\end{array}$} & \multicolumn{2}{|c|}{ Measurement results } & \multirow{2}{*}{ Result } \\
\hline & TANK & WEBSITE & \\
\hline $\begin{array}{c}4 \\
\mathrm{~cm}\end{array}$ & $\begin{array}{l}\text { Minimum distance of } \\
\text { ultasonic sensor } 2 \mathrm{~cm} \\
\text { with disinfectant } \\
\text { liquid. If it is too tight } \\
\text { then the ultrasonic } \\
\text { sensor cannot calculate } \\
\text { the distance with the } \\
\text { disinfectant liquid }\end{array}$ & $\begin{array}{l}\text { Then the result that } \\
\text { appears on the } \\
\text { website is } 4 \mathrm{~cm} \\
\text { between the } \\
\text { ultrasonic sensor } \\
\text { and the disinfectant } \\
\text { liquid }\end{array}$ & Read \\
\hline $20 \mathrm{~cm}$ & $\begin{array}{l}\text { After spraying again } \\
\text { the distance contained } \\
\text { in the berda tengki at } \\
20 \mathrm{~cm}\end{array}$ & $\begin{array}{l}\text { Similarly, the } \\
\text { graphics on the } \\
\text { website are at a } \\
\text { distance of } 20 \mathrm{~cm}\end{array}$ & Read \\
\hline $40 \mathrm{~cm}$ & $\begin{array}{l}\text { when the distance of } \\
\text { disinfectant liquid and } \\
\text { ultrasonic sensor is at } \\
\text { a status of } 40 \mathrm{~cm} \text { then } \\
\text { automatically the } \\
\text { message of depleted } \\
\text { disinfectant will be } \\
\text { directly sent to the } \\
\text { driver of the tank car }\end{array}$ & $\begin{array}{l}\text { After the status of } \\
40 \mathrm{~cm} \text { on the } \\
\text { website, the tool is } \\
\text { dead and can not be } \\
\text { used until refilled } \\
\text { again }\end{array}$ & Read \\
\hline $50 \mathrm{~cm}$ & $\begin{array}{l}\text { When it is at a status of } \\
50 \mathrm{~cm} \text { then the tool can } \\
\text { not work anymore and } \\
\text { can not send the status } \\
\text { of water level on the } \\
\text { website }\end{array}$ & $\begin{array}{l}\text { So that on the } \\
\text { webite does not } \\
\text { change until the } \\
\text { tank is refilled and } \\
\text { the tool is restarted } \\
\text { again }\end{array}$ & $\begin{array}{l}\text { Unrea } \\
\text { dable }\end{array}$ \\
\hline
\end{tabular}

\subsubsection{Test for sending warning SMS}

Testing the SMS gateway is done in the following scenario:

a. The sensor sends a status signal for the disinfectant liquid level after spraying.

b. The web system displays a graph of the disinfectant fluid level.

c. The status in the $4 \mathrm{~cm}$ tank is the closest distance between the ultrasonic sensor and the disinfectant liquid in the tank.

d. The status of the disinfectant liquid level is normal $<10 \mathrm{~cm}$, alert $10 \mathrm{~cm}$ and $30 \mathrm{~cm}$, the tool stops working $40 \mathrm{~cm}$ and $50 \mathrm{~cm}$, the sensor cannot work until the water in the tank is refilled

e. A warning SMS is sent when the disinfectant liquid and the ultrasonic sensor are at the status of $40 \mathrm{~cm}$

f. SMS sent to the tanker officer whose cellphone number has been registere 


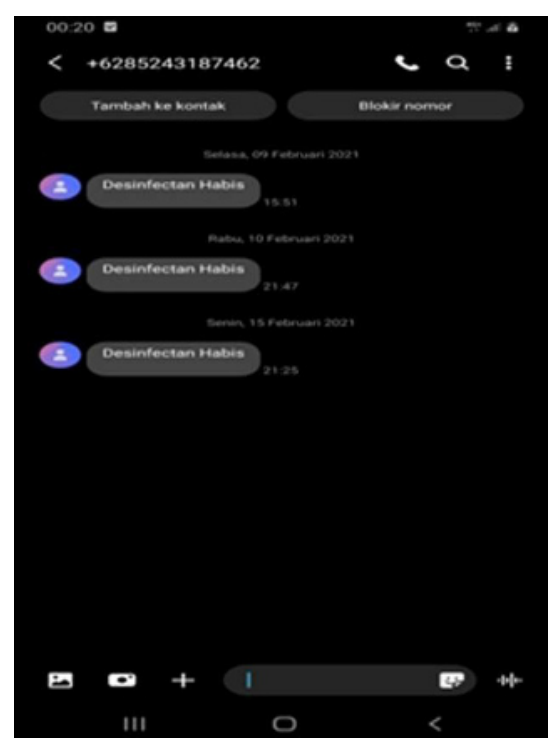

Fig. 8. SMS Delivery Alerts

\subsection{Comparison Results}

After conducting research and testing the entire system design, it can be seen the comparison between the sprayers at the gate of Universitas Musamus and the current spraying can be seen in Table 2 .

Table 2. Comparison result

\begin{tabular}{|c|c|l|l|}
\hline No & Comparison & \multicolumn{1}{c|}{ Old } & \multicolumn{1}{c|}{ New } \\
\hline 1 & Spraying & $\begin{array}{l}\text { Spraying } \\
\text { continuously }\end{array}$ & $\begin{array}{l}\text { Spraying when } \\
\text { someone by passes }\end{array}$ \\
\hline 2 & $\begin{array}{c}\text { Use of } \\
\text { disinfectant } \\
\text { liquids }\end{array}$ & $\begin{array}{l}\text { More } \\
\text { wasteful } \\
\text { because } \\
\text { spraying is } \\
\text { done } \\
\text { continuously }\end{array}$ & $\begin{array}{l}\text { More efficient } \\
\text { because spraying } \\
\text { is only done } \\
\text { when someone by } \\
\text { passes }\end{array}$ \\
\hline 3 & Tank filling & $\begin{array}{l}\text { Sometimes } \\
\text { delays in } \\
\text { recharging }\end{array}$ & $\begin{array}{l}\text { Easier in } \\
\text { informing liquid } \\
\text { disinfectant habis } \\
\text { so that there is no } \\
\text { delay }\end{array}$ \\
\hline
\end{tabular}

\section{Conclusion}

Able to produce a prototype tool for automatic disinfectant spraying system which has been successfully created and simulated. So that this tool can facilitate the spraying of disinfectants and able to build a system on an automatic disinfectant sprayer prototype that is able to provide real time information related to monitoring the contents of the disinfectant tank.

\section{References}

1. Tim Kerja Kementerian Dalam Negeri. Pedoman Umum Menghadapi Pandemi Covid-19 Bagi Pemerintah Daerah: Pencegahan, Pengendalian, Diagnosis dan Manajemen. J. Chem. Inf. Model. 53, 1689-1699 (2013).

2. Kemenkes RI. Pedoman Kesiapsiagaan Menghadapi Infeksi Novel Coronavirus (2019nCov). Direkorat Jenderal Pencegah. dan Pengendali. Penyakit 0-74 (2020).

3. Zubaedah, R., Loppies, S. H. D. \& Putra, N. P. Simulation of Flood Detection System Using Atmega 8535 Microcontroller. in (Atlantis Press, 2018). doi:10.2991/icst-18.2018.114.

4. Putra, N. P. \& Maulany, G. J. Classification System for Student Study Duration on Department of Information Systems At Musamus University, Using Id3. Int. J. Mech. Eng. Technol. 9, 878-885 (2018).

5. Maulany, G. J., Putra, N. P. \& Musamus, U. CLASSIFICATION OF THE LATEST HANDPHONE PRODUCTS IN THE TOKO REJEKI CELULAR IN MERAUKE DISTRICT. 10, 344-351 (2019).

6. Fallis, A.N. Journal of Chemical Information and Modeling, 53(9), pp. 1689-1699. doi: 10.1017/CBO9781107415324.004.o Title No Title. J. Chem. Inf. Model. 53, 1689-1699 (2013).

7. Rachmat Rachmat, T. I. Sistem Penentuan Waktu Simpan Tepung Sagu di Kabupaten Merauke dengan menggunakan Arduino Uno. 7, 1-26 (2018).

8. Simanjuntak, M. G. Perancangan Prototipe Smart Building Berbasis Arduino UNO. Singuda Ensikom 2, 6-31 (2013). 